\title{
Nutrient digestibilities in ingredients fed alone or in combinations
}

\author{
BY INGE HANSEN, T. LARSEN, K. E. BACH KNUDSEN AND B. O. EGGUM \\ National Institute of Animal Science, Animal Physiology and Biochemistry, Foulum, PO Box 39, \\ 8830 Tjele, Denmark
}

(Received 22 January 1990 - Accepted 6 November 1990)

\begin{abstract}
Digestibility coefficients (DC) of protein, dry matter, energy, starch, and dietary fibre in individual feedstuffs were used to predict the DC in feed mixtures. Digestibility studies with growing rats involved six feed sources: soya-bean meal, barley, rapeseed meal, peas, wheat bran and wheat, given individually and in various combinations, i.e. fourteen diets in total. True digestibility of protein (TD) and apparent digestibility of starch could be predicted in feed mixtures from their respective DC values for the individual ingredients, except in the diet composed of peas + barley. Dry matter (DM) and insoluble dietary fibre digestibilities in the mixtures could also be calculated from their individual DC values. Energy digestibility could be predicted in all mixtures except for barley + wheat and peas + wheat. Although the discrepancies were significant, the differences were not great. The digestibility of soluble dietary fibre in the mixtures could be predicted as for the individual ingredients in all but three diets: rapeseed meal + barley, peas + barley and peas + wheat. The results confirm that DC values for TD, DM, energy, starch and dietary fibre in mixtures can be calculated with high precision from DC determined from individual ingredients. Caution should be taken though when mixtures contain a high amount of dietary fibre, especially of the soluble type.
\end{abstract}

Protein: Starch: Dietary fibre: Energy

Digestibility coefficients (DC) for nutrients in feedstuffs are usually given for each ingredient separately. Diet mixtures, however, in most cases contain two or more ingredients and the question is, therefore, whether digestibility of these mixtures can be calculated on the basis of the DC of the individual components.

The response of an animal to a particular protein has been shown to be influenced by the carbohydrate source in the diet, thus indicating an interaction at the digestion site in the gut between some carbohydrate components and protein (Guggenheim et al. 1960; Dahlqvist \& Thomsen, 1964). Eggum \& Christensen (1974) found no significant interaction on either protein digestibility or utilization when autoclaved potato starch was replaced by increasing amounts of the simple sugars glucose, fructose, or sucrose. These results from studies on rats were confirmed in digestibility studies with chickens (Bønsdorff Petersen, 1972) and minks (Mustela vison) (Glem Hansen, 1972). Several digestibility studies have shown that high concentrations of lactose provoke a decreased protein digestibility through its diarrhoeal effect (e.g. Smulikowska et al. 1985) due to a limited lactase activity in the small intestine.

It may, therefore, be assumed that protein digestibility is independent of the dietary carbohydrate source as long as only certain simple carbohydrates are considered. Addition of dietary fibre (DF) has been shown unequivocally to reduce apparent as well as true digestibility (Gallaher \& Schneeman, 1986). However, most of the studies reported in the literature have been performed using a single basic diet supplemented or substituted with 
a single protein source and, thus, give no information on the effects on protein digestibility in mixed feeds where interactions between the various nutrients are likely to occur. No assumptions can be made either on the effect of DF on the DC of other dietary components in feed mixtures.

The present work was undertaken to throw light on the question about interactions between the individual feed ingredients in the digestive system of young animals, especially feedstuffs with different DF levels. DC of protein, dry matter (DM), energy, starch, DF (insoluble (IDF) and soluble (SDF)) were measured in individual feedstuffs and in various combinations.

As the apparent digestibility of fat is dependent on the dietary inclusion rate, fat was not included in the present study. In addition, the fat level in all ingredients included was low but still very different. It was, thus, expected that endogenous fat secretion would mask the results.

\section{EXPERIMENTAL}

\section{Diets}

The design involved six feedstuffs frequently combined in pig diets: soya-bean meal, rapeseed meal, peas, barley, wheat and wheat bran. These were fed individually and in various combinations. A total of fourteen diets were prepared as shown in Table 1. To each diet were added constant levels of minerals and vitamins (Eggum, 1973). The chemical composition of the diets is shown in Table 2.

\section{Animals and feeding}

The general experimental procedure has been described by Eggum (1973). Groups of five Wistar male rats were used per diet. They weighed approximately $70 \mathrm{~g}$ when the experiment started. A preliminary period of $6 \mathrm{~d}$ and a balance period of $5 \mathrm{~d}$ were used. All diets were fed simultaneously at $10 \mathrm{~g} \mathrm{DM} /$ rat per d. Rats given the same diet were placed in a row, i.e. in groups. Earlier tests have shown that the experimental results were independent of where the rats were placed in the room.

True digestible protein (TD), and digestible DM, energy (DE), starch, SDF and IDF were measured. When measuring TD, correction for metabolic nitrogen was performed as described by Eggum (1973). The calculation of digestibility was based on the values obtained when the feedstuffs were given individually. In the calculation of digestibility, the relative proportion from each feedstuff of the various nutrients had to be considered. This is illustrated for protein in a mixture as given below:

$$
\left(P_{1} \times D_{1}+P_{2} \times D_{2}\right) /\left(P_{1}+P_{2}\right)
$$

where $P_{1}$ and $P_{2}$ are g protein $/ \mathrm{kg}$ mixture contributed by ingredients 1 and 2 respectively and $D_{1}$ and $D_{2}$ are their respective DC, determined individually.

\section{Chemical analyses}

DM and $\mathrm{N}$ were determined by standard methods (Association of Official Analytical Chemists, 1975) and starch by the enzymic method described by Bach Knudsen et al. (1987). Total dietary fibre (TDF) content was assayed by a gravimetric method based on enzymic digestion of starch and proteins as described by Asp et al. (1983). According to this method, TDF can be classified into SDF and IDF components. Energy was determined using an adiabatic IKA-Calorimeter Type C 400 (H. Wösthoff pHg, Bochum, Germany). Benzoic acid (BCS-CRM No 190n BAS) was used for calibration. All analyses were performed in duplicate. 
Table 1. Formulation of diets containing either one foodstuff or a combination $(1: 1, w / w$, dry matter $(D M)$ basis) as food sources $(\mathrm{g} / \mathrm{kg} \mathrm{DM})$

\begin{tabular}{|c|c|c|c|c|c|c|c|c|c|c|c|c|c|c|}
\hline Diet no.. & 1 & 2 & 3 & 4 & 5 & 6 & 7 & 8 & 9 & 10 & 11 & 12 & 13 & 14 \\
\hline Soya-bean meal & 944 & - & 472 & - & - & - & - & - & - & - & 472 & - & - & - \\
\hline Barley & - & 944 & 472 & - & 472 & - & 472 & - & 472 & - & - & 472 & - & - \\
\hline Rapeseed meal & - & - & - & 944 & 472 & - & - & - & - & - & - & - & 472 & - \\
\hline Peas & - & - & - & - & - & 944 & 472 & - & - & - & - & - & - & 472 \\
\hline Wheat bran & - & - & - & - & - & - & - & 944 & 472 & - & $\ldots$ & - & - & - \\
\hline Wheat & - & - & - & - & - & - & - & - & - & 944 & 472 & 472 & 472 & 472 \\
\hline Mineral mix* & 40 & 40 & 40 & 40 & 40 & 40 & 40 & 40 & 40 & 40 & 40 & 40 & 40 & 40 \\
\hline Vitamin mix* & 16 & 16 & 16 & 16 & 16 & 16 & 16 & 16 & 16 & 16 & 16 & 16 & 16 & 16 \\
\hline
\end{tabular}

* Composition according to Eggum (1973).

\section{Statistical analysis}

Calculation of digestibility values of the various nutrients in feed mixtures was based on mean values determined on individual feedstuffs. Differences between measured and calculated values were identified by confidence intervals ( $t$ tests). Regression analyses between measured and calculated digestibility values were performed on treatment means (SAS, 1985).

\section{RESULTS}

\section{Chemical composition}

The chemical composition of the fourteen experimental diets is shown in Table 2. The protein content varied from $127.8 \mathrm{~g} / \mathrm{kg} \mathrm{DM}$ in the wheat-barley diet (diet 12) to $520.6 \mathrm{~g} / \mathrm{kg}$ DM in the soya-bean meal diet (diet 1). Starch was lowest in the rapeseed-meal diet (diet 4) with only $10.4 \mathrm{~g} / \mathrm{kg} \mathrm{DM}$, while the wheat diet (diet 10) contained $684.0 \mathrm{~g} / \mathrm{kg} \mathrm{DM}$. The concentration of SDF was generally low with the highest value of $63.0 \mathrm{~g} / \mathrm{kg} \mathrm{DM}$ in peas (diet 6) and the lowest in wheat (diet 10 ), which contained only $17.5 \mathrm{~g} / \mathrm{kg} \mathrm{DM}$. The level of IDF was very high in the wheat-bran diet (diet 8) with $426.4 \mathrm{~g} / \mathrm{kg} \mathrm{DM}$, while the wheat diet (diet 10) contained only $99.7 \mathrm{~g} / \mathrm{kg} \mathrm{DM}$. The gross energy concentration did not vary much and was in the range $18 \cdot 73-20 \cdot 11 \mathrm{MJ} / \mathrm{kg} \mathrm{DM}$.

\section{Digestibility measurements with rats}

The results for all the digestibility measurements of protein, DM, energy, starch, SDF and IDF are presented in Table 3.

TD varied considerably with the lowest value of 0.749 in wheat bran (diet 8 ) and the highest in wheat (diet 10) with 0.930 . Starch was almost completely digested in all but diet 8. The digestibility of SDF varied from 0.669 in wheat bran (diet 8) to 0.905 in barley (diet 2). The values for IDF digestibility were much lower than those for SDF in the range 0.367 for wheat bran (diet 8) to 0.591 for soya-bean meal (diet 1). DM and energy digestibilities were lowest for wheat bran $(0.580,0.578)$ (diet 8$)$ and highest for wheat $(0.904,0.899$; diet 10 ). Tables 4-9 show measured and calculated values for the mixtures together with the differences between these two values.

\section{$T D$}

In Table 4 can be seen the measured and calculated values for TD in the eight mixtures. It appears that only small differences existed, although the calculated value for the peas + barley diet was significantly $(P<0-01)$ higher than the measured value. The same trend could also be seen in the peas + wheat diet, although this difference was not significant. 
Table 3. True digestibility of protein and digestibilities of dry matter (DM), energy, starch, soluble and insoluble dietary fibre (SDF and IDF respectively) in rats of six feedstuffs given individually and in combinations $(1: 1, w / w, D M$ basis $)$

\begin{tabular}{lcccccccccccccc}
\hline \hline Diet no.... & 1 & 2 & 3 & 4 & 5 & 6 & 7 & 8 & 9 & 10 & 11 & 12 & 13 & 14 \\
\hline $\begin{array}{l}\text { Protein } \\
\text { (nitrogen }\end{array}$ & 0.869 & 0.878 & 0.882 & 0.818 & 0.823 & 0.921 & 0.879 & 0.749 & 0.814 & 0.930 & 0.894 & 0.913 & 0.851 & 0.908 \\
$\quad \times 6.25$ ) & & & & & & & & & & & & & & \\
DM & 0.792 & 0.850 & 0.836 & 0.675 & 0.761 & 0.878 & 0.858 & 0.580 & 0.718 & 0.904 & 0.855 & 0.876 & 0.794 & 0.878 \\
Energy & 0.795 & 0.845 & 0.833 & 0.704 & 0.775 & 0.874 & 0.849 & 0.578 & 0.700 & 0.899 & 0.849 & 0.862 & 0.792 & 0.867 \\
Starch & 0.997 & 0.998 & 0.995 & 0.998 & 0.995 & 0.996 & 0.995 & 0.980 & 0.993 & 0.999 & 0.995 & 0.998 & 0.997 & 0.996 \\
SDF & 0.823 & 0.905 & 0.893 & 0.795 & 0.823 & 0.911 & 0.825 & 0.669 & 0.738 & 0.736 & 0.855 & 0.905 & 0.819 & 0.754 \\
IDF & 0.591 & 0.376 & 0.515 & 0.515 & 0.451 & 0.568 & 0.505 & 0.367 & 0.341 & 0.508 & 0.510 & 0.436 & 0.469 & 0.504 \\
\hline
\end{tabular}

Table 4. A comparison of measured and calculated true digestibility of protein in the eight combined diets

\begin{tabular}{clcccc}
\hline \hline $\begin{array}{l}\text { Diet } \\
\text { no. }\end{array}$ & Food source & Measured & $\begin{array}{c}\text { SD } \\
(\mathrm{df} 4)\end{array}$ & Calculated & Difference \\
\hline 3 & Soya-bean meal + barley & 0.882 & 0.012 & 0.870 & $0.012 \mathrm{NS}$ \\
5 & Rapeseed meal + barley & 0.823 & 0.016 & 0.831 & $0.008 \mathrm{NS}$ \\
7 & Peas + barley & 0.879 & 0.012 & 0.907 & $0.028 * *$ \\
9 & Wheat bran + barley & 0.814 & 0.015 & 0.798 & $0.016 \mathrm{NS}$ \\
11 & Soya-bean meal + wheat & 0.894 & 0.011 & 0.882 & $0.012 \mathrm{NS}$ \\
12 & Barley + wheat & 0.913 & 0.011 & 0.907 & $0.006 \mathrm{NS}$ \\
13 & Rapeseed meal + wheat & 0.851 & 0.012 & 0.848 & $0.003 \mathrm{NS}$ \\
14 & Peas +wheat & 0.908 & 0.014 & 0.924 & $0.016 \mathrm{NS}$ \\
\hline \hline
\end{tabular}

NS, not significant.

Calculated value was significantly different from the measured value: ${ }^{* *} P<0 \cdot 01$.

Table 5. A comparison of measured and calculated digestible dry matter $(D M)$ in the eight combined diets

\begin{tabular}{clcccc}
\hline \hline $\begin{array}{c}\text { Diet } \\
\text { no. }\end{array}$ & Food source & $\begin{array}{c}\text { Measured } \\
\text { digestible } \\
\text { DM }\end{array}$ & $\begin{array}{c}\text { SD } \\
\text { (df 4) }\end{array}$ & $\begin{array}{c}\text { Calculated } \\
\text { digestible } \\
\text { DM }\end{array}$ & Difference \\
\hline 3 & Soya-bean meal + barley & 0.836 & 0.013 & 0.821 & $0.015 \mathrm{NS}$ \\
5 & Rapeseed meal + barley & 0.761 & 0.014 & 0.763 & $0.002 \mathrm{NS}$ \\
7 & Peas + barley & 0.858 & 0.008 & 0.862 & $0.004 \mathrm{NS}$ \\
9 & Wheat bran +barley & 0.718 & 0.017 & 0.715 & $0.003 \mathrm{NS}$ \\
11 & Soya-bean meal + wheat & 0.855 & 0.014 & 0.848 & $0.007 \mathrm{NS}$ \\
12 & Barley + wheat & 0.876 & 0.008 & 0.877 & $0.001 \mathrm{NS}$ \\
13 & Rapeseed meal + wheat & 0.792 & 0.012 & 0.789 & $0.003 \mathrm{NS}$ \\
14 & Peas + wheat & 0.878 & 0.010 & 0.888 & $0.010 \mathrm{NS}$ \\
\hline \hline
\end{tabular}

NS, not significant. 
Table 6. A comparison of measured and calculated digestible energy (DE) in the eight combined diets

\begin{tabular}{|c|c|c|c|c|c|}
\hline $\begin{array}{l}\text { Diet } \\
\text { no. }\end{array}$ & Food source & $\begin{array}{l}\text { Measured } \\
\text { DE }\end{array}$ & $\begin{array}{c}\text { SD } \\
(\mathrm{df} 4)\end{array}$ & $\begin{array}{c}\text { Calculated } \\
\text { DE }\end{array}$ & Difference \\
\hline 3 & Soya-bean meal + barley & 0.833 & 0.012 & $0-819$ & $0.014 \mathrm{NS}$ \\
\hline 5 & Rapeseed meal + barley & 0.775 & 0.014 & 0.772 & $0.003 \mathrm{NS}$ \\
\hline 7 & Peas + barley & 0.849 & 0.009 & 0.859 & $0.010 \mathrm{NS}$ \\
\hline 9 & Wheat bran + barley & $0 \cdot 700$ & 0.017 & $0 \cdot 708$ & $0.008 \mathrm{NS}$ \\
\hline 11 & Soya-bean meal + wheat & 0.849 & 0.013 & $0 \cdot 845$ & $0.004 \mathrm{NS}$ \\
\hline 12 & Barley + wheat & 0.862 & 0.007 & 0.871 & $0.009 *$ \\
\hline 13 & Rapeseed meal + wheat & 0.792 & 0.013 & $0 \cdot 798$ & $0.006 \mathrm{NS}$ \\
\hline 14 & Peas + wheat & 0.867 & 0.009 & $0 \cdot 886$ & $0.019 * *$ \\
\hline
\end{tabular}

NS, not significant.

Calculated values were significantly different from the corresponding measured values: ${ }^{*} P<0 \cdot 05,{ }^{* *} P<0 \cdot 01$.

Table 7. A comparison of measured and calculated digestible starch in the eight combined diets

\begin{tabular}{clcccc}
$\begin{array}{c}\text { Diet } \\
\text { no. }\end{array}$ & Food source & $\begin{array}{c}\text { Measured } \\
\text { digestible } \\
\text { starch }\end{array}$ & $\begin{array}{c}\text { SD } \\
\text { (df 4) }\end{array}$ & $\begin{array}{c}\text { Calculated } \\
\text { digestible } \\
\text { starch }\end{array}$ & Difference \\
\hline 3 & Soya-bean meal + barley & 0.995 & 0.003 & 0.996 & $0.001 \mathrm{NS}$ \\
5 & Rapeseed meal + barley & 0.995 & 0.003 & 0.997 & $0.002 \mathrm{NS}$ \\
7 & Peas + barley & 0.995 & 0.001 & 0.997 & $0.002 * *$ \\
9 & Wheat bran + barley & 0.993 & 0.002 & 0.994 & $0.001 \mathrm{NS}$ \\
11 & Soya-bean meal + wheat & 0.995 & 0.005 & 0.997 & $0.002 \mathrm{NS}$ \\
12 & Barley + wheat & 0.998 & 0.004 & 0.998 & $0.000 \mathrm{NS}$ \\
13 & Rapeseed meal + wheat & 0.997 & 0.002 & 0.996 & $0.001 \mathrm{NS}$ \\
14 & Peas +wheat & 0.996 & 0.003 & 0.997 & $0.001 \mathrm{NS}$ \\
\hline
\end{tabular}

NS, not significant.

Calculated value was significantly different from the measured value: ${ }^{* *} P<0 \cdot 01$.

\section{$D M$}

The measured and calculated values for DM digestibility were very similar with no significant differences (Table 5).

\section{$D E$}

As for the digestibility of DM, there were only small differences between the measured and calculated DE values. However, for the diets barley + wheat and peas + wheat, the calculated values were significantly higher than the measured values (Table 6).

\section{Starch}

The digestibility of starch (Table 7$)$ was very high $(>0.99)$ in all diets. However, the calculated value in the peas + barley diet was significantly $(P<0.01)$ higher than the measured value.

\section{$S D F$}

Marked differences between the digestibility measured and calculated for the SDF values were found in the following diets: rapeseed meal + barley, peas + barley and peas + wheat. In all three cases the calculated values were the higher (Table 8). 
Table 8. A comparison of measured and calculated digestible soluble dietary fibre (SDF) in the eight combined diets

\begin{tabular}{cllccl}
\hline $\begin{array}{l}\text { Diet } \\
\text { no. }\end{array}$ & Food source & $\begin{array}{c}\text { Measured } \\
\text { digestible } \\
\text { SDF }\end{array}$ & $\begin{array}{c}\text { SD } \\
\text { (df } 4)\end{array}$ & $\begin{array}{c}\text { Calculated } \\
\text { digestible } \\
\text { SDF }\end{array}$ & Difference \\
\hline 3 & Soya-bean meal + barley & 0.893 & 0.028 & 0.861 & $0.032 \mathrm{NS}$ \\
5 & Rapeseed meal + barley & 0.823 & 0.023 & 0.853 & $0.030^{*}$ \\
7 & Peas + barley & 0.825 & 0.020 & 0.908 & $0.083^{* * *}$ \\
9 & Wheat bran + barley & 0.738 & 0.041 & 0.787 & $0.049 \mathrm{NS}$ \\
11 & Soya-bean meal + wheat & 0.855 & 0.044 & 0.802 & $0.053 \mathrm{NS}$ \\
12 & Barley + wheat & 0.905 & 0.039 & 0.862 & $0.043 \mathrm{NS}$ \\
13 & Rapeseed meal + wheat & 0.819 & 0.035 & 0.780 & $0.039 \mathrm{NS}$ \\
14 & Peas + wheat & 0.754 & 0.050 & 0.873 & $0.119 * *$ \\
\hline
\end{tabular}

NS, not significant.

Calculated values were significantly different from the corresponding measured value: ${ }^{*} P<0.05,{ }^{* *} P<0.01$, *** $P<0 \cdot 001$.

Table 9. A comparison of measured and calculated digestible insoluble dietary fibre (IDF) in the eight combined diets

\begin{tabular}{cllccc}
\hline $\begin{array}{l}\text { Diet } \\
\text { no. }\end{array}$ & Food source & $\begin{array}{c}\text { Measured } \\
\text { digestible } \\
\text { IDF }\end{array}$ & $\begin{array}{c}\text { SD } \\
\text { (df 4) }\end{array}$ & $\begin{array}{c}\text { Calculated } \\
\text { digestible } \\
\text { IDF }\end{array}$ & Difference \\
\hline 3 & Soya-bean meal + barley & 0.515 & 0.028 & 0.496 & $0.019 \mathrm{NS}$ \\
5 & Rapeseed meal + barley & 0.451 & 0.031 & 0.470 & $0.019 \mathrm{NS}$ \\
7 & Peas + barley & 0.505 & 0.027 & 0.475 & $0.030 \mathrm{NS}$ \\
9 & Wheat bran + barley & 0.341 & 0.031 & 0.369 & $0.028 \mathrm{NS}$ \\
11 & Soya-bean meal + wheat & 0.510 & 0.045 & 0.563 & $0.053 \mathrm{NS}$ \\
12 & Barley+wheat & 0.436 & 0.020 & 0.429 & $0.007 \mathrm{NS}$ \\
13 & Rapeseed meal + wheat & 0.469 & 0.041 & 0.513 & $0.044 \mathrm{NS}$ \\
14 & Peas + wheat & 0.504 & 0.035 & 0.545 & $0.041 \mathrm{NS}$ \\
\hline
\end{tabular}

NS, not significant.

\section{$I D F$}

There were no significant differences between the measured and calculated values for the digestibility of IDF (Table 9).

\section{Regression analysis}

Regression analyses between measured $(X)$ and calculated $(Y)$ digestibility (based on mean values) are shown in Table 10. From these equations it appears that a highly significant relationship between calculated and measured digestibility exists for protein, DM, DE and IDF, whereas this was not the case for starch and SDF. It should be stressed that the intercept values for both starch and SDF differed significantly from zero which is theoretically impossible.

\section{DISCUSSION}

The diets in the present study were composed to have a big diversity in their chemical composition. The intention with this was to measure if interaction was more likely under extreme dietary composition compared with traditional diets. 
Table 10. The relationships between measured $(X$, independent variable) and calculated $(Y$, dependent variable) digestibility of nutrients

\begin{tabular}{ll}
\hline TD: & $Y=-0.0659+1.0761 \times X, R^{2} 0.75, P<0.001$, SE 0.1668 \\
DM: & $Y=-0.0217+1.0247 \times X, R^{2} 0.99, P<0.001$, SE 0.0515 \\
DE: & $Y=-0.0103+1.0174 \times X, R^{2} 0.97, P<0.001$, SE 0.0732 \\
Starch: & $Y=0.4366+0.5625 \times X, R^{2} 0.25, P>0.05$, SE 0.2268 \\
SDF: & $Y=0.6845+0.1890 \times X, R^{2} 0.06, P>0.05$, SE 0.3058 \\
IDF: & $Y=0.0491+0.9292 \times X, R^{2} 0.76, P<0.01$, SE 0.2151 \\
\hline
\end{tabular}

TD, true digestible protein; DM, dry matter; DE, digestible energy; SDF, soluble dietary fibre ; IDF, insoluble dietary fibre.

Earlier work at our institute (Bønsdorff Petersen, 1972; Glem Hansen, 1972; Eggum \& Christensen, 1974) has demonstrated that different types of sugars and starch do not affect protein digestibility or protein utilization. This is in contrast to the studies of, for example Guggenheim et al. (1960) and Dhalqvist \& Thomsen (1964).

In the present study we found a highly significant relationship between the calculated and measured TD for all diets but the peas + barley mixture. The probable reason for the calculated TD being higher than the measured value is that there is an increased faecal excretion of microbial biomass due to the high bacterial growth in the hind-gut when legumes are fed (Eggum \& Beames, 1981). Legumes contain a relatively high amount of soluble DF which is easily fermented and, thus, stimulatory for the bacterial growth in the hind-gut (e.g. Nyman \& Asp, 1982). The same tendency was also seen when wheat was fed together with peas. The results in Table 7 show that starch digestibility was very much the same and close to 1.00 for the measured as well as the calculated values. This explains why no significant relationship existed between measured and calculated starch digestibility. However, with values close to unity there is a danger with proportions. A further statistical test using transformation data was not performed.

DM digestibility was not affected by interactions and there was a highly significant $(P<0.001)$ relationship between the calculated and measured values. For DE there were interactions in the barley + wheat and peas + wheat diets, although the differences between calculated and measured DE were only marginal. The relationship between calculated and measured DE was also highly significant $(P<0.001)$.

There were no significant differences between IDF digestibility when measured and calculated. On the other hand, there were significant interactions for digestible SDF in three of the diets; rapeseed meal + barley, peas + barley and peas + wheat. In all three cases the calculated digestible SDF was significantly higher than the measured value. The reason for this might be that the bacterial biomass contains significant amounts of polysaccharides in their cell walls (McAllan, 1985).

The conclusion to be drawn from the present study is that interactions between various dietary nutrients in digestibility measurements is not a major problem. The only dietary substance that seems to cause interaction in certain dietary mixtures is SDF. However, generally SDF only makes up a small proportion of the total diets so the issue may not be of much importance. For the digestibility of protein, DM, energy, starch and IDF, interactions do not seem to be a major problem.

\section{Concluding remarks}

Minor differences in the calculated and measured DC of protein, DM, energy, starch, and dietary fibre indicate only marginal interactions in the digestive system of young growing rats.

The only feed mixtures to cause concern are products containing high concentrations of 
dietary fibre, especially SDF. The reason for discrepancies might be due to changes in transit time, the presence of inhibitors affecting digestibility events, or a change in the microbial activity of the hind-gut.

\section{REFERENCES}

Asp, N.-G., Johansson, C.-G., Hallmer, H. \& Siljeström, M. (1983). Rapid enzymatic assay of insoluble and soluble fiber. Journal of Agricultural and Food Chemistry 31, 476-482.

Association of Official Analytical Chemists (1975). Official Methods of Analysis, 1 lth ed. Washington, DC: Association of Official Analytical Chemists.

Bach Knudsen, K. E., Eggum, B. O. \& Åman, P. (1987). Nutritive value of Danish-grown barley varieties. I. Carbohydrates and other major constituents. Journal of Cereal Science 6, 173-186.

Bønsdorff Petersen, C. (1972). Fordøjelighed og omsættelig energi i majsstivelse, glukose, sakkarose og laktose samt indflydelsen på kvælstoffets omsætning målt i forsøg med kyllinger. Digestibility and metabolizable energy in maize starch, glucose, saccharose and lactose and the influence on nitrogen metabolism measured in experiments with chickens. Weekly Report for Agronomists and Horticulturists 43, 872-876.

Dahlquist, A. \& Thomsen, D. L. (1964). The digestion and absorption of lactose by the intact rat. Acta Physiologica Scandinavica 61, 20-33.

Eggum, B. O. (1973). A study of certain factors influencing protein utilization in rats and pigs. National Institute of Animal Science, Det Kgl. danske Landhusholdningsselskab, Rolighedsvej 26, Copenhagen, Report no. 406, p. 173. Copenhagen: National Institute of Animal Science.

Eggum, B. O. \& Beames, R. M. (1981). The effect of varying crude protein and the proportions of fibre in diets containing a mixture of meat-and-bone meal and wheat bran as the only protein source on nitrogen balance indices and energy digestibility in the rat. British Journal of Nutrition 46, 301-313.

Eggum, B. O. \& Christensen, K. D. (1974). Protein digestibility of a feed mixture in relation to the protein digestibility of the individual protein components. British Journal of Nutrition 31, 213-218.

Gallaher, D. \& Schneeman, B. (1986). Effect of dietary fiber on protein digestibility and utilization. In Handbook of Dietary Fiber in Human Nutrition, pp. 143-164 [G. A. Spiller, editor]. Boca Raton, Florida: CRC Press.

Glem Hansen, N. (1972). The influence of carbohydrate source on protein digestibility and utilization in mink. Yearbook, Agricultural Research Laboratory, Copenhagen, pp. 231-232. Copenhagen: National Institute of Animal Science.

Guggenheim, K., Halevy, S. \& Friedmann, N. (1960). Levels of lysine and methionine in portal blood of rats following protein feeding. Archives of Biochemistry and Biophysics 91, 6-10.

McAllan, A. B. (1985). Analysis of carbohydrate in the alimentary tract and its nutritional significance. In Analysis of Food Carbohydrates, pp. 269-297 [G. G. Birch, editor]. London and New York: Elsevier Applied Science Publishers.

Nyman, M. \& Asp, N.-G. (1982). Fermentation of dietary fibre components in the rat intestinal tract. British Journal of Nutrition 47, 357-366.

SAS (1985). User's Guide. Statistics. Cary, N.C.: Statistical Analysis System Institute Inc.

Smulikowska, S., Eggum, B. O. \& Wolstrup, J. (1985). The influence of moderate lactose intake on intestinal lactase activity, protein utilization and energy digestibility in rats. Zeitschrift für Tierphysiologie, Tierernährung und Futtermittelkund 53, 225-232. 